\title{
Engaged Learning in MOOCs for Teaching Professional Development in the Cyber Era: A Study of Autoethnography
}

\author{
Candradewi Wahyu Anggraeni \\ Universitas Tidar, Jl. Kapten Suparman 39 Potrobangsan, Magelang Utara, Indonesia
}

\{candradewi@untidar.ac.id\}

\begin{abstract}
In the Cyber Era, numerous learning platforms exist to fulfill the learners' needs. One of the platforms is MOOCs (Massive Open Online Courses) in which it provides many materials for promoting autonomous learning. In this research, I implement an autoethnography to share my experiences in joining MOOCs that cover ways to use MOOCs, MOOCs materials, MOOCs assignments completion, and benefits and obstacles in MOOCs. This research uses a qualitative approach that focuses on my learning experiences in MOOCs. The instruments of data collection used are my systematic learning observation and my journal reflection. IMOOC (Indonesian Massive Open Online Course) on Technology for Autonomous Learning 2018 and MOOC AE-E Teacher Program Fall 2018 are the MOOCs that I involve in. Being an enrollee in MOOCs, I can gain many virtues for my teaching professional development. In short, this research will give the contribution to theoretical, practical, and pedagogical significances toward MOOCs.
\end{abstract}

Keywords: MOOCs, autoethnography, cyber era, teaching professional development

\section{INTRODUCTION}

In the cyber era, the use of technology plays an important role particularly in an educational system. The supported educational system covers several aspects. One of the aspects is in the teaching and learning process. The success of teaching and learning process cannot be separated from the educational platform or learning management system. In the development of educational platform, MOOCs (Massive Open Online Courses) straightly become phenomenal platform due to it has many virtues to support teaching and learning process in this cyber era. [1] MOOCs are able to be used as ancillary materials for teaching and learning. It can be inferred that by joining MOOCs, the learners can gain knowledge to support their learning toward certain courses in which the courses fulfill the learners' need. The notion of MOOCs derives to the idea the learning development in the cyber era. [2] "MOOC is a recent development of this open learning movement, which have drawn much attention from both academic and the public sphere." It shows that MOOCs can be one of alternative educational platforms that help the learners to be autonomous learners. 
The trend of MOOCs reveals the idea of promoting open online courses in the universities. [3-4] MOOCs are free and up to date online courses in which the learners enroll them for free instruction, so learners can access MOOCs. Moreover, there are several characteristics of MOOCs. "Among the characteristics of MOOCs is Massive, which means MOOCs easily accommodate large numbers of students; Openness, which involves several key concepts: software, registration, curriculum and assessment, communication including interaction, collaboration, sharing and learning environments" [3]. Those key concepts need to be highlighted for those who enroll in MOOCs in order to pass the courses and reach the learning goal. Another research also follow up that the main characteristic of MOOCs is online and free. "A Massive Open Online Course (MOOC) is a type of online course characterized by large-scale student participation and open access via the Internet. The "Open" part of the MOOC acronym signifies "free" to many people - as in "free to students" [5].

Enrolling in MOOCs courses is one of epic ways to enrich teaching professional development in this cyber era. The development of technology provides many educational platforms that support teachers' professional development. Teachers' Professional Development (TPD) derives to the idea of developing teachers' four competencies that cover pedagogy, professionalism, personality, and social in order to reach the great development of teaching and learning process. [6] "TPD can be considered as an ongoing process of education, training, learning and support activities which is: taking place in either external or work-based settings; engaged in by qualified, educational professionals; aimed mainly at promoting learning and development of their professional knowledge, skills and values; to help decide and implement valued changes in their teaching and learning behavior so that they can educate their students more effectively thus achieving an agreed balance between individual, school and national need." Regarding to the notion of TPD, it means that I need to enhance my teaching professional development by participating in one of the activities that support the chain of TPD.

Virtues of MOOCs for TPD show the important reasons of enrolling MOOCs. [6] MOOCs help the teachers to explore how to conduct teaching online, to participate in community that has same interests, to deliver e-learning or e-live students experience by having online class, to learn new materials in a structured way, and to find free supported resources toward certain topics. Referring to the epiphany of joining MOOCs for teaching professional development, I have valuable experiences in exploring the path of MOOCs. This study declares my learning experiences in MOOCs and the virtues of joining MOOCs for my teaching professional development.

\section{METHODOLOGY}

Autoethnograpy is used as the research design in this study. [7] Autoethnography is the combination between autobiography and ethnography in which it describes about researcher's personal experiences (my experiences) toward certain phenomenon. Autoethnography is a part of life history research. [8] Life history is the study of the individuals' life experiences from the viewpoints of how these individuals grasp the phenomenon in their surroundings in which the terms can be called as a biography, a life story, an oral history, a case study, an autobiography, a memoir. In this study, the autoethnography, a life history, is applied as the consideration to get the points for the research topic of MOOCs for teaching professional development. "In educational setting, life history has become a popular approach for studying teacher development." [8]

The subject of the study is the researcher (I) who has already experienced MOOCs (IMOOC and AE-E Teacher). Moreover, there are several steps of the data collection 
procedures. The first step is I surf the IMOOC (Indonesian Massive Open Online Course) and AE-E Teacher program in the platform named Canvas. I focus on the learning history of my participation in joining those MOOCs program. The second step is I describe my past learning experiences and write them in the form of reflexive log in order to keep my learning history in MOOCs. The third step is I recap the given materials and the shared assignments that I have done.

Regarding the data collection instruments, there are several instruments for a life history which consist of diaries, correspondence, professional writing, interview, direct observation, and narrative analysis [8]. Besides, the instruments of data collection used in this study are systematic learning observation in the form field notes and journal reflection in reflexive log. I record my MOOCs learning activities in the reflexive log. When I have already got the data, I analyze the data qualitatively. I sort the data in which they fulfill to answer my research questions. The data are categorized into several themes as the result of this study. Furthermore, the research procedure covers several parts that includes deciding the research phenomenon, deciding the research design, exploring the significances of the research, deciding the instrument of data collection, collecting the data, analyzing the data, displaying the finding, delivering the discussion and conclusion of the study.

\section{FINDING AND DISCUSSION}

\subsection{Learning Journey in IMOOC}

One of the big steps in developing my teaching professional development is by enrolling MOOCs and being an elusive course participant in MOOCs. I have to struggle in my MOOCs due to I need to complete my MOOCs and to do my job. It can be stated that I am required to be multitasking person for achieving my goal to be a professional teacher/ lecturer. In achieving my goal, I enroll MOOCs. The first MOOC is IMOOC (Indonesian Massive Open Course) on Technology for Autonomous Learning. IMOOC is the program that is initiated by The U.S. Embassy's Regional English Language Office (RELO) and has team work with fifteen Indonesian university professors from around Indonesia to develop the courses. The Indonesian developers decide to use Canvas E-learning platform as the platform to promote MOOC in Indonesia. The participants in IMOOC that I involve in are thirty (30) participants who are mostly from Central Java.

Furthermore, I join IMOOC in January 14 - May 5, 2018. It takes 82.5 hours for completing the courses. Several steps are passed in joining IMOOC as follows.

a. Getting the information about MOOCs

b. Completing the requirement by taking the online selection.

c. Having face to face meeting as the introduction sessions with IMOOC facilitator and participants for getting know each other.

d. Having the course tutorial to access Canvas as IMOOC platform.

e. Exploring the Canvas platform.

f. Learning the materials given and doing assignments in IMOOC through Canvas.

g. Having online farewell with all IMOOC participants as the IMOOC completion and getting the certificate.

In completing IMOOC, I have a facilitator who is patient and discipline in guiding IMOOC participants. As IMOOC is the open online course, WhatsApp group is also used as the communication platform between the facilitator and participants in order to ease the 
completion of IMOOC program. Based on the field notes, it is captured that the materials and assignments in IMOOC train me as a lecturer to develop my teaching. The spread of materials and assignments can be seen below.

Table 1 IMOOC Materials and Assignments for Teaching Professional Development

\begin{tabular}{|c|c|c|c|}
\hline No & Materials/ Modules & Assignments & Teaching Professional Development \\
\hline 1 & $\begin{array}{l}\text { Understanding } \\
\text { Autonomous Learning }\end{array}$ & $\begin{array}{l}\text { Understanding the } \\
\text { Concept of } \\
\text { Autonomous Learning, } \\
\text { Autonomous Learning } \\
\text { Model, Using an App to } \\
\text { Promote Autonomous } \\
\text { Learning }\end{array}$ & $\begin{array}{l}\text { I promote autonomous learning in my } \\
\text { teaching by using several autonomous } \\
\text { learning model and applying several } \\
\text { applications for supporting } \\
\text { autonomous learning. }\end{array}$ \\
\hline 2 & Digital Literacy & $\begin{array}{l}\text { Understanding Digital } \\
\text { Literacy, Digital } \\
\text { Literacy for } 21 \mathrm{st} \\
\text { Century Teachers, } \\
\text { Creating Infographic } \\
\text { about Digital Literacy }\end{array}$ & $\begin{array}{l}\text { It helps me in understanding the } \\
\text { concept of digital literacy in which it } \\
\text { supports my teaching especially in } \\
\text { this cyber era. }\end{array}$ \\
\hline 3 & $\begin{array}{l}\text { Mobile Devices for } \\
\text { Autonomous Teaching } \\
\text { and Learning }\end{array}$ & $\begin{array}{l}\text { Mobile Apps Ideas, } \\
\text { Selecting Mobile Apps, } \\
\text { Creating Teaching } \\
\text { Materials Using an App }\end{array}$ & $\begin{array}{l}\text { I apply several mobile apps in my } \\
\text { teaching. Therefore, my students are } \\
\text { more interested in joining the } \\
\text { teaching and learning process when } \\
\text { I use educational mobile apps. }\end{array}$ \\
\hline 4 & $\begin{array}{l}\text { Promoting Autonomous } \\
\text { Learning Using Videos }\end{array}$ & $\begin{array}{l}\text { The Importance of } \\
\text { Using Video in the } \\
\text { Classroom, Effective } \\
\text { Educational Video, } \\
\text { Creating Tasks Using } \\
\text { Videos }\end{array}$ & $\begin{array}{l}\text { I use the videos for supporting my } \\
\text { teaching and learning process. } \\
\text { Therefore, the students are more } \\
\text { active in joining the discussion. }\end{array}$ \\
\hline 5 & $\begin{array}{l}\text { Autonomy for Video } \\
\text { Creation }\end{array}$ & $\begin{array}{l}\text { Using Video in the } \\
\text { Classroom, Creating } \\
\text { a Video, Creating } \\
\text { a Lesson Plan }\end{array}$ & $\begin{array}{l}\text { It helps me to make my students } \\
\text { become autonomous learners. I ask } \\
\text { my students to create a video in } \\
\text { a group. The students show their } \\
\text { creativity in creating the video. }\end{array}$ \\
\hline
\end{tabular}

Based on Table 1, it shows that I get many benefits for my teaching professional development by joining IMOOC. IMOOC provides many supported learning modules that promote autonomous learning in which it is one of core learning in the cyber era. In the cyber era, the students are the millennial generations that are easy to follow the development of technology. Therefore, I must follow the development of technology for supporting my teaching and learning process. Besides, it is essential to catch up the knowledge in IMOOC for promoting autonomous learning in order to develop my instruction.

\subsection{Learning Journey in AE-E Teacher}

After completing IMOOC, I am nominated to join AE-E Teacher. AE-E Teacher is a MOOC program initiated by U.S. Department of State, FHI 360, and Iowa State University. The main goal of AE-E Teacher is to help the participants to be professional teachers. I enroll AE-E Teacher in September 25 - November 20, 2018 with the topic Using Educational Technology in the English Language Classroom. The participants of AE-E Teacher are one 
hundred and seventy three (173) who are from around the world such as Indonesia, Malaysia, Thailand, Philippines, Vietnam, United States, Serbia, Turkey, Montenegro, Brazil, Oman, Angola, Bangladesh, Chile, and etc.

In joining AE-E Teacher, I must follow several stages like joining IMOOC. The difference is in the session of self-introduction. The AE-E Teacher participants introduce themselves in Canvas platform due to the participants are from many countries around the world. Furthermore, AE-E Teacher gives huge opportunity for my teaching professional development. I can share my teaching experiences to another teacher around the world and vice versa.

As an elusive AE-E Teacher completer, I have a Teaching Assistant (TA) from Iowa State University who guide me to complete AE-E Teacher program. According to the field notes of joining AE-E Teacher, several important parts are pointed them out for teaching professional development as follows.

Table 2 AE-E Teacher Materials and Assignments for Teaching Professional Development

\begin{tabular}{|c|c|c|c|}
\hline No & Materials/ Modules & Assignments & Teaching Professional Development \\
\hline 1 & $\begin{array}{l}\text { Introduction to } \\
\text { Technology for English } \\
\text { Language Learning }\end{array}$ & $\begin{array}{l}\text { Technology Experts } \\
\text { Video, Reaction to } \\
\text { Technology Expert } \\
\text { Video }\end{array}$ & $\begin{array}{l}\text { I apply this knowledge in my teaching } \\
\text { especially in this cyber era in which } \\
\text { technology plays a core role. }\end{array}$ \\
\hline 2 & $\begin{array}{l}\text { Vocabulary and } \\
\text { Technology }\end{array}$ & $\begin{array}{l}\text { Sharing Experiences } \\
\text { with Vocabulary } \\
\text { Teaching, Using } \\
\text { Technology to Teach } \\
\text { Vocabulary, Using } \\
\text { Social Media to Teach } \\
\text { Vocabulary }\end{array}$ & $\begin{array}{l}\text { I get many teaching experiences from } \\
\text { others when they teach vocabulary by } \\
\text { using technology and social media. } \\
\text { I also implement the use of } \\
\text { technology in teaching vocabulary. }\end{array}$ \\
\hline 3 & $\begin{array}{l}\text { Teaching Grammar } \\
\text { Using Technology }\end{array}$ & $\begin{array}{l}\text { Exploring Grammar } \\
\text { Teaching Resources, } \\
\text { Grammar Teaching } \\
\text { Materials Development }\end{array}$ & $\begin{array}{l}\text { I implement several grammar } \\
\text { teaching resources to ease my } \\
\text { students understand the grammar } \\
\text { materials. }\end{array}$ \\
\hline 4 & $\begin{array}{l}\text { How to Select Reading } \\
\text { Texts }\end{array}$ & $\begin{array}{l}\text { Implementing Reading } \\
\text { Activities, Reflecting on } \\
\text { How to find reading } \\
\text { text, Analyzing Reading } \\
\text { Text }\end{array}$ & $\begin{array}{l}\text { I try to find suitable reading texts that } \\
\text { are based on students" proficiency. }\end{array}$ \\
\hline 5 & $\begin{array}{l}\text { Writing and } \\
\text { Technology }\end{array}$ & $\begin{array}{l}\text { Approaches to Writing } \\
\text { and Technology, Using } \\
\text { Technology for } \\
\text { Teaching Writing, } \\
\text { Collaborative Writing }\end{array}$ & $\begin{array}{l}\text { I apply the use of technology in my } \\
\text { writing class by considering the } \\
\text { approaches to teach writing using } \\
\text { technology. }\end{array}$ \\
\hline
\end{tabular}

Referring Table 2, it indicates that AE-E Teacher program proposes valuable experiences that help me to achieve the goal of my teaching professional development. AE-E Teacher facilitates the participants to develop their instructions in teaching vocabulary, grammar, reading, and writing by using technology. The materials/modules and assignments given support my teaching and learning process in this cyber era. 


\subsection{Benefits and Obstacles in MOOCs}

Based on the reflexive log, I find many virtues of enrolling MOOCs. MOOCs develop four aspects of being a professional teacher or lecturer. The four competencies are pedagogy, professionalism, personality, and social. The pedagogy and professionalism competencies are revealed by the materials shared in modules and the assignments given that focus on Technology for Autonomous Learning and topic Using Educational Technology in the English Language Classroom. Those materials help me to develop my pedagogy and professionalism competencies in delivering materials by using technology, designing the lesson plan, promoting autonomous learning, applying the educational technology platform to support my instruction.

The personality competency is exposed by doing the assignments in IMOOC and AE-E Teachers. MOOCs assignments are required me to be discipline, punctual, independent, and autonomous learner due to the assignments have strict deadline. If I submit the assignments late, I will get the point's reduction. Besides, several rules must be obeyed to pass MOOCs. Moreover, the social competency is shown in the way among participants to communicate each other. The communication happens when each participant gives feedback for other participants' works in the discussion board. I learn a lot how to communicate, socialize, and respect with many people from different educational background, different country, and different culture. I have to pay attention to the way I share my ideas in the discussion and give my feedback so that there is no misunderstanding or misconception among us as the participants in MOOCs.

Those benefits help me to reach my teaching professional development in this cyber era. I utilize all concepts that I have got in MOOCs in my classroom. Currently, I have promoted MOOC in my instructions. I develop my own MOOC for my students. I have already created Canvas for my classes. I apply the knowledge that I get in IMOOC and AE-E Teacher for my own MOOC.

On the other hand, I have found several obstacles in MOOCs. Sometimes, it is difficult to manage my time well. When there is deadline for the assignment, I must be struggle in doing the assignments on time due to I have many things to be finished too. Therefore, it is important for me as the participant to have a great commitment in completing MOOCs. The next obstacle is when I have to learn something new; I need extra time to grasp the materials and to implement it in my instruction. However, it is challenging to understand something new.

\section{CONCLUSIONS}

The trend of MOOCs arises currently in this cyber era in which it provides virtues and hurdles. In this study, I use an autoethnography as a part of life history research that focuses on learning experiences, benefits, and obstacles in enrolling IMOOC and AE-E Teacher. MOOCs learning experiences build my teaching professional development so that they can be stated as valuable programs for supporting teachers or lecturers' professional development. Many advantages can be taken by joining MOOC. The obstacles of participating in MOOCs can be handled as long as the participants have high commitment to pass the MOOCs program. It is suggested for the others, particularly teachers and lecturers to join MOOCs in order to face the development of education in this cyber era and to improve teachers' professional development. All in all, it is hoped that there will be another researchers who concern in MOOCs for enriching the researches toward MOOCs. 


\begin{abstract}
About Author
Candradewi Wahyu Anggraeni is a lecturer of English Education Study Program, Faculty of Education and Teachers' Training at Universitas Tidar (UNTIDAR) in Magelang, Central Java, Indonesia. She has been teaching for three years. She is interested in conducting the research in the area of writing, listening, the use of technology in teaching and learning process, and MOOCs. For further information about this article, it can be addressed to Candradewi via email candradewi@untidar.ac.id.
\end{abstract}

\title{
References
}

[1] A. Aziz, "Evaluating the Design Standard of UiTM Massive Open Online Courses," International Journal of Education \& Literacy Studies, vol.6, no.4, Oct., pp. 138-151, 2018.

[2] O.W. Richter, A. Bozkurt, U. Alturki, and A. Aldraiweesh, "What Research Says About MOOCs - An Explorative Content Analysis", International Review of Research in Open and Distributed Learning, vol.19, no.1, pp. 242-259, 2018.

[3] M.Tahiru and R. Kamaludeen, "Indicators of Students' Intention to Use Massive Open Online Courses for Academic Purposes", Malaysian Online Journal of Educational Technology, vol.6, no.3, pp. 52-62, 2018.

[4] S.J. Blackmon, and C.H. Major, "Wherefore Art Thou MOOC?: Defining Massive Open Online Courses", Online Learning Journal, vol.21, issue.4, pp. 195-221, 2017.

[5] R.M. Baker, and D.L. Passmore, "Value and Pricing of MOOCs", Education Science, vol. 6, no. 14, pp. 1-11, 2016.

[6] P.M. Misra, "MOOCs for Teacher Professional Development: Reflections, and Suggested Actions", Open Praxis, vol. 10, issue 1, pp. 67-77, 2018.

[7] J.R.Malin, "MOOCing On Up? Experiences of an Elusive Course Completer", MidWestern Educational Research, vol.27, issue. 1, pp. 31-50, 2015.

[8] M.D. Gall, J.P.Gall, and W.R. Borg, "Educational Research: An Introduction", Boston: Pearson Education Inc, 2003. 